\title{
PENGARUH PEMBERIAN JUS CAMPURAN BUAH LABU KUNING DAN TOMAT TERHADAP PENURUNAN TEKANAN DARAH LANSIA HIPERTENSI
}

\author{
${ }^{1}$ Dali, ${ }^{2}$ Nurjannah, ${ }^{3}$ Taamu \\ ${ }^{1,2,3}$ Staf Dosen Jurusan Keperawatan Poltekkes Kendari
}

\begin{abstract}
Abstrak
Penelitian ini bertujuan untuk mengetahui efektivitas pemberian jus campuran buah labu kuning (cucurbita maxima) dan tomat (lyopercisum esculentum) terhadap penurunan tekanan darah pada lansia hipertensi. Metode penelitian ini adalah quasi experiment dengan pre test and post test design with control group. Populasi dalam penelitian adalah semua lansia hipertensi yang berada dan terdaftar di Posyandu Lansia Mata Bubu Wilayah Kerja Puskesmas Poasia Kota Kendari Tahun 2016 sebanyak 33 orang. Jumlah sampel adalah 30 lansia yang dibagi menjadi dua kelompok yaitu 15 orang kelompok intervensi dan 15 orang kelompok kontrol. Hasil penelitian menunjukan bahwa pemberian jus campuran buah labu kuning (Cucurbita maxima) dan tomat (Lyopercisum esculentum) efektif menurunkan tekanan darah pada lansia hipertensi masing-masing untuk tekanan darah sistole $(p=0,022 ; \alpha=0,05)$, dan tekanan darah diastole $(p=0,046 ; \alpha=0,05)$.
\end{abstract}

Kata Kunci : Hipertensi, Labu Kuning, Lansia, Tekanan Darah, Tomat.

\begin{abstract}
This study aims to determine the effectiveness of a mixture of fruit juice of pumpkin (Cucurbita maxima) and tomatoes (lyopercisum esculentum) to decrease blood pressure in elderly hypertensive. This research method was quasi experimental with pre-test and post-test design with control group. The population in this study are all elderly and hypertension were enrolled in Posyandu Elderly Mata Bubu Puskesmas Poasia Kendari 2016 as many as 33 people. The total sample was 30 elderly people who were divided into two groups: 15 people the intervention group and 15 control group. The results showed that administration of a mixture of fruit juice of pumpkin (Cucurbita maxima) and tomatoes (Lyopercisum esculentum) is effective in lowering blood pressure in elderly hypertensive respectively for systolic blood pressure ( $p=0.022$; $\alpha=$ 0.05), and diastolic blood pressure $(p=0.046$; $\alpha=0.05)$.
\end{abstract}

Keyword: Hypertension, Pumpkin Yellow, Elderly, Blood Pressure, Tomato.

\section{PENDAHULUAN}

Hipertensi identik dengan

peningkatan tekanan darah melebihi batas normal (Mahmudah dkk, 2015). Menurut World Health Organization (WHO) bahwa batas normal tekanan darah adalah 120 $140 \mathrm{mmHg}$ tekanan sistolik dan $80-90$ $\mathrm{mmHg}$ tekanan diastolik. Seseorang dinyatakan mengidap hipertensi bila tekanan darahnya > 140/90 mmHg. Prevalensi hipertensi di Indonesia sebesar $26,5 \%$ pada tahun 2013 , tetapi yang terdiagnosis oleh tenaga kesehatan dan/atau riwayat minum obat hanya sebesar 9,5\%).

Berdasarkan data Dinas Kesehatan Provinsi Sulawesi Tenggara, prevalensi kejadian hipertensi tahun 2011 adalah 40.001 kasus (58\%), tahun 2012 sebanyak $37.036(56 \%)$ kasus dan tahun 2013 sebesar 24.414 kasus (51\%) (Dinkes Prov.Sultra, 2014). Meskipun terjadi penurunan, namun kasus hipertensi masih berada pada 10 kasus penyakit terbesar di 
Sulawesi Tenggara. Data tersebut menunjukkan bahwa masalah hipertensi di Sulawesi Tenggara perlu mendapat perhatian dan penanganan yang baik mengingat prevalensi dan akibat yang timbul cukup tinggi. Masalah hipertensi yang paling umum terjadi pada lansia sebab Prevalensi hipertensi meningkat dengan bertambahnya usia, hal ini dipertegas dengan hasil penelitian wahyuningsih dan Endriastuti, (2013) bahwa faktor umur dapat mempengaruhi kejadian hipertensi. Senada dengan itu, Nuraini (2015) juga menyatakan bahwa dengan bertambahnya umur maka tekanan darah juga akan meningkat. Data dari Puskesmas Poasia Kota Kendari pada bulan Oktober 2015, menunjukkan bahwa di Posyandu Lansia Mata Bubu menempati jumlah persentase tertinggi usia lanjut yang menderita hipertensi yaitu 36 orang $(52,17 \%)$ dari 69 orang lansia yang ada di Posyandu tersebut.

Oleh karena tingginya Lansia yang menderita hipertensi, maka perlu suatu intervensi yang aman bagi Lansia. Berbagai upaya telah dilakukan untuk menurunkan angka kejadian penyakit hipertensi, sementara kecenderungan penderita hipertensi pada lansia senantiasa meningkat. Obat yang paling umum digunakan untuk menurunkan tekanan darah pada penderita hipertensi adalah pemberian obat modern dari dokter. Penggunaan obat hipertensi modern berupa obat kimiawi dapat menimbulkan efek samping apabila penggunaannya tidak tepat, oleh karena itu obat tradisional dari ramuan obat alami dapat menjadi pilihan. Banyak obat tradisional yang dapat digunakan sebagai alternatif penurunan hipertensi, diantaranya adalah buah labu kuning dan Tomat.

Labu kuning (Cucurbita moschata Durch) merupakan jenis tanaman sayuran yang memiliki kandungan gizi yang cukup lengkap yakni karbohidrat, protein, beberapa mineral seperti kalsium, fosfor, besi, serta vitamin yaitu Vitamin B dan $C$ dan serat. Warna kuning atau oranye daging buahnya pertanda kandungan karotenoidnya sangat tinggi (Ranonto dkk, 2015). Labu kuning merupakan sumber karotenoid, pektin, garam mineral, vitamin dan zat bioaktif lainnya, seperti senyawa fenolik (Cerniauskiene et al., 2014). Tomat juga bias menjadi pilihan yang baik untuk menurunkan tekanan darah tinggi. Buah tomat memiliki banyak kandungan zat yang berkhasiat yaitu pigmen lycopene (berfungsi sebagai antioksidan yang melumpuhkan radikal bebas, menyeimbangkan kadar kolesterol darah dan tekanan darah (Raharjo, 2010). Karena banyaknya Khasiat labu kuning dan tomat ini, disinyalir dapat dimanfaatkan untuk menurunkan hipertensi pada lansia secara maksimal jika diberikan dalam bentuk campuran jus labu kuning dan tomat.

\section{METODE PENELITIAN}

Penelitian ini dilaksanakan pada bulan Agustus sampai Oktober 2016 di Posyandu Lansia Mata Bubu Wilayah Kerja Puskesmas Poasia Kota Kendari. Penelitian ini didesain untuk mengetahui kemungkinan adanya hubungan sebab akibat yang muncul setelah diberikan intervensi atau perlakuan pada suatu variabel, kemudian hasil dari perlakuan tersebut dibandingkan dengan kelompok kontrol yaitu kelompok yang tidak dikenakan perlakuan (Notoatmodjo, 2005). Bentuk desain penelitiannya adalah sebagai berikut:

Tabel 1. Desain Penelitian

\begin{tabular}{lcll}
\hline Kelompok & Pretest & Intervensi & Postest \\
\hline Perlakuan & $\mathrm{O}_{1}$ & $\mathrm{X}$ & $\mathrm{O}_{2}$ \\
\hline Kontrol & $\mathrm{O}_{3}$ & - & $\mathrm{O}_{4}$ \\
\hline
\end{tabular}

Keterangan:

O1 : Tekanan darah pada kelompok perlakuan sebelum intervensi pemberian Jus campuran buah labu kuning dan tomat. O2 : Tekanan darah pada kelompok perlakuan setelah intervensi pemberian Jus campuran buah labu kuning dan tomat.

$X$ : Intervensi, memberikan jus campuran buah labu kuning dan tomat. 
O3 : Tekanan darah pada kelompok kontrol sebelum kelompok perlakuan diberikan jus campuran buah labu kuning dan tomat .

O4 : Tekanan darah pada kelompok kontrol setelah kelompok perlakuan diberikan jus campuran buah labu kuning dan tomat.

Populasi dalam penelitian ini adalah seluruh usia lanjut yang mengalami hipertensi di Posyandu Lansia Mata Bubu Wilayah Kerja Puskesmas Poasia Kota Kendari yang berjumlah 36 orang. Sampel dalam penelitian ini adalah usia lanjut yang berada di Posyandu Lansia Mata Bubu Wilayah Kerja Puskesmas Poasia Kota Kendari yang berjumlah 30 orang. Sampel dibagi menjadi 2 kelompok yaitu: 15 orang kelompok intervensi, dan 15 orang kelompok kontrol. Teknik sampling yang digunakan adalah simple random sampling. Sampel yang digunakan memenuhi kriteria inklusi sebagai berikut:

1. Lansia yang telah berusia $\geq 60$

2. Menderita Hipertensi

3. berdomisili di wilayah kerja puskesmas Poasia Kota kendari

4. Bersedia menjadi Responden

Untuk menghindari kesalahpahaman dan perbedaan penafsiran yang berkaitan dengan istilah-istilah dalam penelitian ini, serta menghindari kesesatan dalam pengukuran dan pengumpulan data maka diberikan definisi operasional variabel yang disajikan pada tabel 2 berikut:

\section{Tabel 2. Definisi Operasional}

\begin{tabular}{|c|c|c|}
\hline No & Variabel & Definisi Operasional \\
\hline 1 & Lansia & 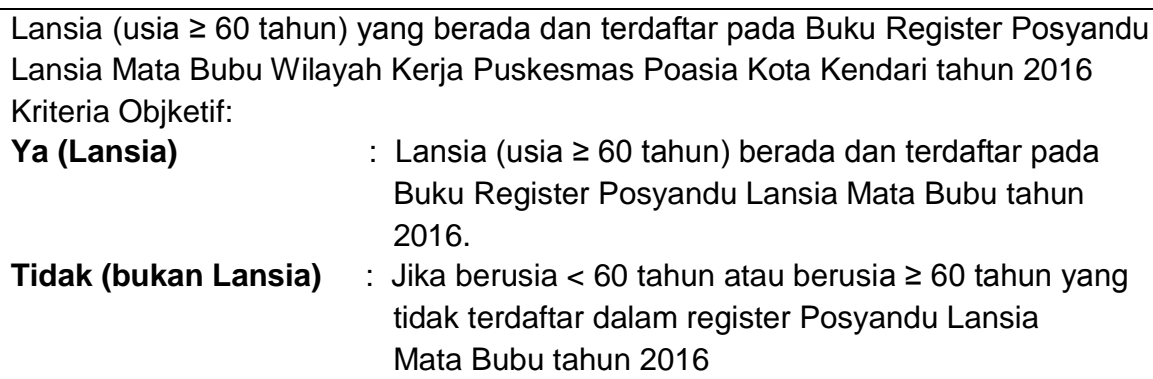 \\
\hline 2 & Hipertensi & 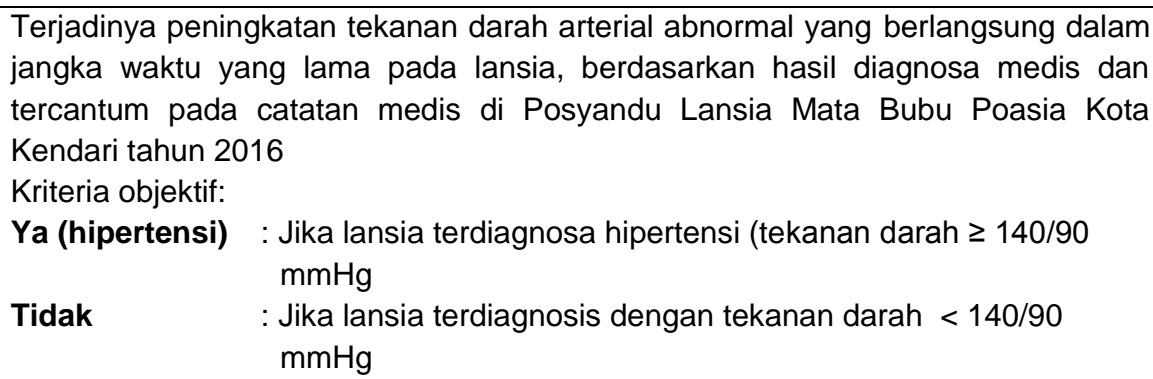 \\
\hline 3 & $\begin{array}{l}\text { Penurunan } \\
\text { tekanan darah }\end{array}$ & $\begin{array}{ll}\begin{array}{l}\text { Terjadinya penurunan tekanan darah pada usia lanjut sebagai efek dari perlakuan } \\
\text { Kriteri Objektif : } \\
\text { Ya (Penurunan) }\end{array} & \begin{array}{l}\text { : Bila terjadi hasil pengukuran tekanan darah setelah } \\
\text { perlakuan lebih rendah dari pada sebelum perlakuan. }\end{array} \\
\text { Tidak } & \begin{array}{l}\text { : Bila pengukuran tekanan darah setelah perlakuan hasilnya } \\
\text { tetap atau lebih tinggi dari pada sebelum perlakuan }\end{array}\end{array}$ \\
\hline 4 & Pemberian jus & $\begin{array}{l}\text { Pemberian jus campuran buah labu } 100 \mathrm{gr} \text {, tomat } 100 \mathrm{gr} \text {, gula pasir } 40 \mathrm{gram} \text {, dan } \\
\text { air } 100 \mathrm{ml} \text { selama } 10 \text { hari. Pemberian dilakukan sebanyak } 1 \text { kali perhari pada } \\
\text { waktu pagi dengan total pemberian } 10 \text { kali selama penelitian berlangsung } \\
\text { Kriteria Objektif : } \\
\text { Ya (Diberikan) : Jika dilakukan pemberian sesuai pedoman dengan total } 10 \\
\text { kali. } \\
\text { Tidak } \quad \text { : Jika pemberian tidak sesuai pedoman dengan total } 10 \text { kali }\end{array}$ \\
\hline
\end{tabular}


Hipotesis dalam penelitian ini yaitu:

Ho : Pemberian jus campuran buah labu kuning dan tomat tidak efektif menurunkan tekanan darah pada lansia hipertensi di Posyandu Lansia Mata Bubu Wilayah Kerja Puskesmas Poasia Kota Kendari Tahun 2016.

$\mathrm{Ha}$ : Pemberian jus campuran buah labu kuning dan tomat efektif menurunkan tekanan darah pada lansia hipertensi di Posyandu Lansia Mata Bubu Wilayah Kerja Puskesmas Poasia Kota Kendari Tahun 2016.

Teknik analisis data dilakukan secara univariat dan bivariat. Secara univariat dilakukan untuk mendiskripsikan setiap variabel yang diteliti dalam penelitian, yaitu untuk melihat distribusi variabel karakteristik responden dan variabel dependen penurunan tekanan darah pada usia lanjut. Secara bivariat dilakukan untuk melihat sebaran responden pada variabel penelitian sebelum dan setelah intervensi serta menguji variabel-variabel penelitian yaitu variabel independen (bebas) dan variabel dependen (terikat).

Uji statistik dalam penelitian ini diawali dengan uji normalitas data menggunakan uji Shapiro-Wilk pada tingkat kebermaknaan 95\% atau $\alpha=0,05$. Hasil uji normalitas menunjukkan bahwa data sebelum dan sesudah perlakuan berdistribusi normal dimana $P$-Value $=0,08>\alpha=0,05$. Dengan demikian analisis bivariat yang digunakan adalah uji analisis komparatif (uji beda) yang dijabarkan berikut ini :

a. Uji beda dua mean sampel berpasangan (dependen). Uji ini digunakan untuk menguji kemaknaan perbedaan mean variabel penelitian antara sebelum dan setelah intervensi. Uji yang digunakan adalah paired t test

b. Uji beda dua mean sampel tidak berpasangan (independen). Uji ini digunakan untuk menguji kemaknaan perbedaan mean variabel penelitian antara kelompok intervensi dan kelompok kontrol. Uji yang digunakan adalah pooled t test.
HASIL PENELITIAN

1. Gambaran Tekanan Darah Lansia Hipertensi Sebelum dan Sesudah Dilakukan Pemberian Jus Campuran Buah Labu Kuning dan Tomat

Tabel 3. Distribusi Tekanan Darah pada Kelompok Intervensi

\begin{tabular}{ccc}
\hline \multirow{2}{*}{$\begin{array}{c}\text { Tekanan } \\
\text { Darah }\end{array}$} & \multicolumn{2}{c}{ Mean (SD) } \\
\cline { 2 - 3 } & Sebelum & Sesudah \\
\hline \multirow{2}{*}{ Sistole } & 156,67 & 138,67 \\
& $(20,931)$ & $(15,976)$ \\
\hline \multirow{2}{*}{ Diastole } & 96,67 & 89,33 \\
& $(4,880)$ & $(7,037)$ \\
\hline
\end{tabular}

Hasil analisis distribusi lansia hipertensi berdasarkan tekanan darah sistole pada kelompok intervensi diperoleh data bahwa sebelum dilakukan intervensi pemberian jus campuran buah labu kuning dan tomat rata-rata tekanan darah sistole lansia adalah 156,67 $\mathrm{mmHg}$ dengan SD 20,931, sedangkan setelah pemberian jus campuran buah labu kuning dan tomat ratarata tekanan darah sistole adalah 138,067 dengan SD 15,976.

Hasil analisis distribusi lansia hipertensi berdasarkan tekanan darah diastole pada kelompok intervensi diperoleh data bahwa sebelum dilakukan intervensi pemberian pemberian jus campuran buah labu kuning dan tomat rata-rata tekanan darah diastole lansia adalah $96,67 \mathrm{mmHg}$ dengan SD 4,880, sedangkan setelah intervensi pemberian jus campuran buah labu kuning dan tomat rata-rata tekanan darah diastole adalah 89,33 dengan SD 7,037.

Tabel 4. Distribusi Tekanan Darah pada Kelompok Kontrol

\begin{tabular}{cll}
\hline \multirow{2}{*}{$\begin{array}{c}\text { Tekanan } \\
\text { Darah }\end{array}$} & \multicolumn{2}{c}{ Mean (SD) } \\
\cline { 2 - 3 } & \multicolumn{1}{c}{ Sebelum } & Sesudah \\
\hline \multirow{2}{*}{ Sistole } & $\begin{array}{l}152,67 \\
(15,337)\end{array}$ & $\begin{array}{l}153,33 \\
(17,182)\end{array}$ \\
\hline \multirow{2}{*}{ Diastole } & 96,00 & 94,00 \\
& $(5,071)$ & $(5,071)$ \\
\hline
\end{tabular}


Hasil analisis distribusi lansia hipertensi berdasarkan tekanan darah sistole pada kelompok kontrol diperoleh data bahwa sebelum dilakukan intervensi pemberian jus campuran buah labu kuning dan tomat rata-rata tekanan darah sistole lansia adalah $152,67 \mathrm{mmHg}$ dengan SD 15,337, sedangkan setelah intervensi pemberian jus campuran buah labu kuning dan tomat rata-rata tekanan darah sistole adalah 153,33 dengan SD 17,182.

Hasil analisis distribusi lansia hipertensi berdasarkan tekanan darah diastole pada kelompok kontrol diperoleh data bahwa pada saat sebelum dilakukan intervensi pemberian jus campuran buah labu kuning dan tomat rata-rata tekanan darah diastole lansia adalah $96,00 \mathrm{mmHg}$ dengan SD 5,071, sedangkan setelah intervensi pemberian jus campuran buah labu kuning dan tomat rata-rata tekanan darah diastole adalah 94,00 dengan SD 5,071

\section{Analisis Efektifitas Pemberian Jus Campuran Buah Labu Kuning dan Tomat Terhadap Penurunan Tekanan Darah Pada Lansia Hipertensi}

Analisis perbedaan tekanan darah lansia hipertensi sebelum dan sesudah intervensi pada kelompok intervensi dilakukan analisis bivariat untuk menjawab hipotesis penelitian. Tabel 5 menunjukan hasil analisis perbedaan tekanan darah lansia hipertensi pada kelompok intervensi sebelum dan sesudah intervensi.
Rata-rata tekanan darah sistole lansia hipertensi sebelum dilakukan intervensi pemberian jus campuran buah labu kuning dan tomat adalah $156,67 \mathrm{mmHg}$ dengan standar deviasi 20,931. Sesudah dilakukan intervensi didapatkan rata-rata tekanan darah sistole lansia hipertensi adalah $138,67 \mathrm{mmHg}$ dengan standar deviasi 15,076. Hasil analisis didapatkan bahwa ada perbedaan tekanan darah systole lansia hipertensi sebelum dan sesudah dilakukan intervensi pemberian jus campuran buah labu kuning dan tomat yaitu rata-rata tekanan darah sistole lansia hipertensi sesudah dilakukan intervensi pemberian jus campuran buah labu kuning dan tomat lebih rendah dibandingkan sebelum intervensi pemberian jus campuran buah labu kuning dan tomat $(p=0,000 ; \alpha=0,05)$.

Rata-rata tekanan darah diastole lansia hipertensi sebelum dilakukan intervensi pemberian jus campuran buah labu kuning dan tomat adalah $96,67 \mathrm{mmHg}$ dengan standar deviasi 4,880. Sesudah dilakukan intervensi didapatkan rata-rata tekanan darah diastole lansia hipertensi adalah $89,33 \mathrm{mmHg}$ dengan standar deviasi 7,037 . Hasil analisis didapatkan bahwa ada perbedaan tekanan darah diastole lansia hipertensi sebelum dan sesudah dilakukan intervensi pemberian jus campuran buah labu kuning dan tomat $(p=0,000 ; \alpha=0,05)$.

Hasil analisis perbedaan tekanan darah pada lansia hipertensi kelompok kontrol sebelum dan sesudah intervensi dapat dilihat pada Tabel 6 .

Tabel 5. Analisis Perbedaan Tekanan Darah pada Kelompok Intervensi

\begin{tabular}{|c|c|c|c|c|c|}
\hline \multicolumn{2}{|c|}{ Tekana Darah } & \multirow{2}{*}{$\begin{array}{c}\text { Mean } \\
156,67\end{array}$} & \multirow{3}{*}{$\begin{array}{c}\begin{array}{c}\text { Beda } \\
\text { Mean }\end{array} \\
18,00\end{array}$} & \multirow{3}{*}{$\begin{array}{c}\text { SD } \\
20,931 \\
15,976\end{array}$} & \multirow{3}{*}{$\begin{array}{r}\text { P-value } \\
0,000\end{array}$} \\
\hline Sistole & Sebelum intervensi & & & & \\
\hline & Sesudah Intervensi & 138,67 & & & \\
\hline \multirow[t]{2}{*}{ Diastole } & Sebelum Intervensi & 96,67 & \multirow{2}{*}{7,34} & 4,880 & \multirow{2}{*}{0,000} \\
\hline & Sesudah Intervensi & 89,33 & & 7,037 & \\
\hline
\end{tabular}


Tabel 6. Analisis Perbedaan Tekanan Darah pada Kelompok Kontrol

\begin{tabular}{|c|c|c|c|c|c|}
\hline \multicolumn{2}{|c|}{ Tekana Darah } & Mean & $\begin{array}{l}\text { Beda } \\
\text { Mean }\end{array}$ & SD & P-value \\
\hline \multirow[t]{2}{*}{ Sistole } & Sebelum intervensi & 152,67 & \multirow{2}{*}{$-0,66$} & 15,337 & \multirow{2}{*}{0,792} \\
\hline & Sesudah Intervensi & 153,33 & & 17,182 & \\
\hline \multirow[t]{2}{*}{ Diastole } & Sebelum Intervensi & 96,00 & \multirow{2}{*}{2,00} & 5,071 & \multirow{2}{*}{0,082} \\
\hline & Sesudah Intervensi & 94,00 & & 5,071 & \\
\hline
\end{tabular}

Tabel 7. Analisis Perbedaan Tekanan Darah Responden Sesudah Intervensi

\begin{tabular}{llccc}
\hline \multicolumn{2}{c}{ Tekana Darah } & Mean & SD & \multirow{2}{*}{ P-value } \\
\cline { 1 - 3 } Sistole & Intervensi & 138,67 & 15,976 & \multirow{2}{*}{0,022} \\
\cline { 1 - 3 } & Kontrol & 153,33 & 17,182 & \\
\cline { 1 - 3 } Diastole & Intervensi & 89,33 & 7,037 & \multirow{2}{*}{0,046} \\
\cline { 1 - 3 } & Kontrol & 94,00 & 5,071 & \\
\hline
\end{tabular}

Rata-rata tekanan darah sistole lansia hipertensi pada kelompok kontrol sebelum dilakukan intervensi pemberian jus campuran buah labu kuning dan tomat adalah $152,67 \mathrm{mmHg}$ dengan standar deviasi 15,337. Sesudah dilakukan intervensi didapatkan rata-rata tekanan darah sistole lansia hipertensi adalah $153,33 \mathrm{mmHg}$ dengan standar deviasi 17,182. Hasil analisis didapatkan bahwa tidak ada perbedaan tekanan darah systole lansia hipertensi pada kelompok kontrol sebelum dan sesudah dilakukan intervensi pemberian jus campuran buah labu kuning dan tomat $(p=0,1792 ; \alpha=0,05)$.

Rata-rata tekanan darah diastole lansia hipertensi pada kelompok kontrol sebelum dilakukan intervensi pemberian jus campuran buah labu kuning dan tomat adalah $96,00 \mathrm{mmHg}$ dengan standar deviasi 5,071 . Sesudah dilakukan intervensi pemberian jus campuran buah labu kuning dan tomat didapatkan rata-rata tekanan darah diastole lansia hipertensi adalah $94,00 \mathrm{mmHg}$ dengan standar deviasi 5,071. Hasil analisis didapatkan bahwa tidak ada perbedaan tekanan darah diastole lansia hipertensi pada kelompok control sebelum dan sesudah dilakukan intervensi pemberian jus campuran buah labu kuning dan tomat ( $p$ $=0,082 ; \alpha=0,05$ ).
Analisis perbedaan tekanan darah lansia hipertensi antara kelompok intervensi dan kelompok kontrol, sesudah intervensi pemberian jus campuran buah labu kuning dan tomat menggunakan uji beda dua mean sampel tidak berpasangan (pooled $t$ test) ditunjukkan pada tabel 7. Terdapat perbedaan tekanan darah sistole antara kelompok intervensi dan kelompok kontrol sesudah dilakukan intervensi pemberian jus campuran buah labu kuning dan tomat $(\mathrm{p}=$ 0,$022 ; \alpha=0,05$ ). Disamping itu pula didapatkan ada perbedaan tekanan darah diastole antara kelompok intervensi dan kelompok kontrol sesudah dilakukan intervensi pemberian jus campuran buah labu kuning dan tomat $(p=0,046 ; \alpha=0,05)$.

\section{PEMBAHASAN}

Hasil penelitian ini menunjukkan bahwa ada perbedaan pemberian jus campuran buah labu kuning dan tomat terhadap penurunan tekanan darah lansia hipertensi yang ditunjukan dengan penurunan tekanan darah baik tekanan darah sistole maupun diastole pada kelompok intervensi pemberian jus. Secara khusus penelitian juga menunjukan bahwa terdapat 1 responden mengalami penurunan tekanan darah setelah dilakukan pemberian 
jus campuran buah labu kuning dan tomat, tetapi tetap berada dalam kategori hipertensi berat yaitu 190/100 mmHg. Meskipun sudah 10 kali pemberian jus campuran buah labu kuning dan tomat dengan tekanan darah sistole menurun sebesar $30 \mathrm{mmHg}$ tetapi masih dalam kategori hipertensi berat, dan tekanan diastolenya tetap sebesar 100 $\mathrm{mmHg}$ masih dalam kategori hipertensi sedang. Hal ini dapat disebabkan karena penyakit hipertensi yang dialaminya merupakan genetik dari orang tuanya yang tidak dapat dikendalikan sehingga akan cenderung menetap dan sulit untuk disembuhkan. Hasil ini seseuai dengan temuan Arifin dkk (2016) yang mnyatakan bahwa faktor genetik mempertinggi risiko terkena penyakit hipertensi, yakni lansia yang memiliki riwayat hipertensi pada keluarga mempunyai risiko untuk menderita hipertensi 1,417 kali lebih besar dibandingkan dengan lansia yang tidak memiliki riwayat hipertensi pada keluarga.

Pada penelitian ini juga ditemukan pula terdapat 3 responden yang tidak mengalami penurunan tekanan darah, meskipun terjadi penurunan tekanan darah systole sebesar 20-30 $\mathrm{mmHg}$, namun tekanan darah diastolenya tidak mengalami penurunan meskipun telah diberikan 10 kali intervensi pemberian jus campuran buah labu kuning dan tomat, namun masih tetap berada dalam kategori hipertensi ringan dan sedang sesudah intervensi pemberian jus campuran buah labu kuning dan tomat. Hal ini disebabkan karena responden ini semuanya mengatakan tidak bisa mengurangi garam dalam menunya setiap hari, sehingga walaupun telah 10 kali intervensi pemberian jus buah labu kuning dan tomat tekanan darah diastolenya tidak mengalami penurunan. Kondisi ini dapat dipengaruhi oleh adanya konsumsi garam yang mengandung natrium. Temuan ini sejalan dengan pendapat Mahmudah dkk (2015) bahwa Asupan natrium berhubungan dengan kejadian hipertensi yang memiliki resiko 4,627 kali lebih besar untuk mengalami kejadian hipertensi. Hal ini didukung juga hasil temuan Wahyuningsih dan Astuti (2013) yang menyatakan bahwa konsumsi garam sangat mempengaruhi terjadinya hipertensi pada usia lanjut.

Rata-rata tekanan darah sistole lansia hipertensi pada kelompok Hipertensi sebelum dilakukan intervensi pemberian jus campuran buah labu kuning dan tomat adalah $156,67 \mathrm{mmHg}$ dengan standar deviasi 20,931. Sesudah dilakukan intervensi didapatkan rata-rata tekanan darah sistole lansia hipertensi adalah $138,67 \mathrm{mmHg}$ dengan standar deviasi 15,976. Hal ini menunjukan bahwa terjadi penurunan tekanan darah sistole lansia hipertensi sesudah diberikan intervensi pemberian jus campuran buah labu kuning dan tomat sebesar $18 \mathrm{mmHg}$. Pada kelompok kontrol, rata-rata tekanan darah sistole lansia hipertensi sebelum dilakukan pemberian campuran jus campuran buah labu kuning dan tomat adalah $152,67 \mathrm{mmHg}$ dengan standar deviasi 15,337. Sesudah intervensi, rata-rata tekanan darah sistole adalah $153,33 \mathrm{mmHg}$ dengan standar deviasi 17,182. Hal ini menunjukan bahwa terjadi peningkatan tekanan darah sistole lansia hipertensi kelompok kontrol sebesar $0,66 \mathrm{mmHg}$.

Tekanan darah rata-rata diastole pada kelompok intervensi sebelum dilakukan pemberian jus campuran buah labu kuning dan tomat adalah $96,67 \mathrm{mmHg}$ dengan standar deviasi 4,880, dan sesudah dilakukan intervensi didapatkan rata-rata tekanan darah diastole adalah $89,33 \mathrm{mmHg}$ dengan standar deviasi 7,037. Hal ini menunjukan bahwa terjadi penurunan tekanan darah diastole lansia dengan hipertensi sesudah diberikan intervensi pemberian jus campuran buah labu kuning dan tomat sebesar $7,34 \mathrm{mmHg}$. Sedangkan pada kelompok kontrol, rata-rata tekanan darah diastole lansia hipertensi sebelum dilakukan pemberian jus campuran buah labu kuning dan tomat adalah $96,00 \mathrm{mmHg}$ dengan standar deviasi 5,071, Sesudah dilakukan intervensi rata-rata tekanan darah sistole adalah $94,00 \mathrm{mmHg}$ dengan standar deviasi 5,071. Hal ini menunjukan bahwa terjadi peningkatan tekanan darah diastole 
lansia hipertensi pada kelompok kontrol sebesar 2,00 mmHg.

Selanjutnya untuk membuktikan efektifitas pemberian jus campuran buah labu kuning dan tomat dalam menurunkan tekanan darah pada lansia hipertensi dilakukan uji statistik dengan paired $t$ test. Hasil uji paired t test menunjukan bahwa pemberian jus campuran buah labu kuning dan tomat efektif menurunkan tekanan darah pada lansia hipertensi di Posyandu Lansia Mata Bubu Wilayah Kerja Puskesmas Poasia Kendari masing-masing didapatkan pada tekanan darah sistole $(p=0,022 ; \alpha=0,05)$, dan tekanan darah diastole $(p=0,046 ; \alpha=0,05)$. Oleh karena itu maka pemberian jus campuran buah labu kuning dan tomat efektif menurunkan tekanan darah pada lansia hipertensi.

Hasil temuan ini didukung pula oleh berbagai penelitian yang telah dilakukan oleh Pakar Gizi dan kesehatan menyimpulkan bahwa buah labu kuning memiliki manfaat yang sangat besar bagi kesehatan, dapat menyembuhkan berbagai penyakit termasuk menurunkan tekanan darah pada hipertensi. Valenzuela et al dalam Suwanto dk (2015) menyatakan bahwa Tanaman labu kuning juga dapat digunakan sebagai obat tradisional sebagai anti diabetes, anti hipertensi, anti tumor, immunomodulasi, dan anti bakteri karena banyak mengandung nutrisi dan senyawa bioaktif seperti fenolat, flavonoid, vitamin (termasuk vitamin $\beta$-karoten, vitamin $A$, vitamin B2, $\alpha$-tokoferol, vitamin $\mathrm{C}$, dan vitamin E. Kandungan kimia flavonoid pada labu kuning berfungsi untuk mengurangi terjadinya plek dan penggumpalan darah sehingga menyebabkan peredaran darah menjadi lancar. Selain itu, dapat meningkatkan aktifitas vitamin $\mathrm{C}$ sebagai antioksidan mencegah oksidasi LDL kolesterol yang dapat mengakibatkan kerusakan dinding pembulu arteri (proses awal terjadinya atherosklerosis) dan menghambat penggumpalan pada dinding pembuluh darah penyebab tekanan darah tinggi.
Dipilinnya buah labu kuning dan tomat sebagai bahan pembuatan jus karena merupakan salah satu alternatif yang efektif menurunkan tekanan darah sebagaimana beberapa penelitian sebelumnya menjelaskan adanya kandungan zat gizi buah labu kuning dan tomat yang dapat menurunkan tekanan darah yaitu: kalium, flavonoid, dan lypocene.

Selain itu, buah labu kuning dan tomat dalam bentuk jus akan memudahkan penyerapan diusus halus, dan bagi lansia tentunya akan memudahkan untuk mengunyah dan menelan. Disamping itu, buah labu kuning dan tomat di Wilayah Kerja Puskemas Poasia Kota Kendari merupakan produk lokal yang mudah tumbuh dipekarangan rumah, mudah diperoleh karena tersedia setiap hari dengan harga yang relatif murah. Cara untuk mendapatkan manfaat konsumsi jus campuran buah labu kuning dan tomat, maka jus campuran buah labu kuning dan tomat harus dikonsumsi secara rutin setiap hari, dan sebaiknya dikonsumsi pada waktu pagi sebelum berktifitas guna memperoleh penyerapan dan metabolisme yang maksimal. Konsumsi jus campuran buah labu kuning dan tomat sekali sehari secara rutin sebanyak 10 kali akan terasa efek positifnya menurunkan tekanan darah pada individu yang hipertensi.

\section{KESIMPULAN}

Distribusi tekanan darah sistole maupun diastole lansia dengan hipertensi sebelum dilakukan intervensi pemberian jus campuran buah labu kuning (Cucurbita maxima) dan tomat (Lyopercisum esculentum) rata-rata tekanan darah lansia hipertensi pada kelompok intervensi dan kelompok kontrol hampir sama. Sedangkan setelah intervensi pemberian jus campuran buah labu kuning dan tomat rata-rata tekanan darah sistole maupun diastole pada kelompok intervensi lebih rendah dari pada kelompok kontrol. Ini berarti bahwa pemberian jus campuran buah labu kuning (Cucurbita maxima) dan tomat (Lyopercisum esculentum) efektif menurunkan tekanan 
darah pada lansia hipertensi di Posyandu Lansia Mata Bubu Wilayah Kerja Puskesmas Poasia Kendari baik tekanan sistole maupun diastole masing-masing untuk tekanan darah sistole $(p=0,022$; $\alpha=0,05)$, dan tekanan darah diastole $(p=0,046 ; \alpha=0,05)$.

\section{SARAN}

Lansia yang mengalami hipertensi dapat melakukan terapi jus campuran buah labu kuning dan tomat melalui bimbingan tenaga kesehatan yang kompeten. Terapi semacam ini dapat dilakukan tanpa biaya jika masyarakat dapt memanfaatkan pekarangan rumahnya dengan menanam labu kuning dan tomat. bagi Puskesmas agar pemberian jus campuran buah labu kuning dan tomat dapat dimasukan dalam Standar penatalaksanaan nonfarmakologis khususnya pada penderita hipertensi

\section{DAFTAR PUSTAKA}

Arifin M.H.B, Weta I.W, Ratnawati N.K.A. 2016. Faktor-Faktor yang Berhubungan dengan Kejadian Hipertensi pada Kelompok Lanjut Usia. E-JURNAL MEDIKA, 5(7): $1-23$

Cerniauskiene, J., J. Kulaitiene., $H$. Danilcenko., E. Jariene, dan E. Jukneviciene. 2014. Pumpkin fruit flour as a source for food enrichment in dietary fiber. Not Bot Horti Agrobo.42(1):19-23.

Mahmudah S, Maryusman T, Arini F.A, Malkan I. 2015. Hubungan Gaya Hidup dan Pola Makan Dengan Kejadian Hipertensi pada Lansia di Kelurahan Sawangan Baru. Biomedika, 7 (2): 4351

Notoatmodjo, S. 2005. Metodologi Penelitian Kesehatan. Edisi Revisi. Jakarta: Rineka Cipta

Nuraini B. 2015. Risk Factors of Hypertension. J Majority . 4 (5): 10-19

Raharjo P. 2010. Pengaruh Pemberian Jus Tomat Terhadap Perubahan Tekanan Darah Sistolik Dan Diastolik Pada Penderita Hipertensi. Jurnal Keperawatan. 1(2): $138-143$

Ranonto N.V, Nurhaeni, Razak.A.B. 2015. Retensi Karoten Dalam Berbagai Produk Olahan Labu Kuning (Cucurbita moschata Durch). Online Jurnal of Natural Science Vol 4(1):104-110

Suwanto, Suranto, Purwanto.E. 2015. Karekterisasi Labu Kuning (Cucurbita moschata Duch) pada Lima Kabupaten di Propinsi Jawa Timur. EL-VIVO. 3 (1): $61-71$

Wahyuningsih dan Astuti E. 2013. Faktor Yang Mempengaruhi Hipertensi pada Usia Lanjut. JNKI, 1(3): 71-75. 